\title{
HISTORICAL DEVELOPMENT OF NON GOVERNMENTAL ORGANISATIONS IN NEPAL
}

\section{Sharada Singh*}

\begin{abstract}
Non-Governmental Organizations are considered one of the major actors in the socio-economic development process. The northern countries and international agencies consider them as alternate institutional mechanisms for the transfer of resources to and also for understanding the reality of the developing countries. The southern countries are increasingly taking these entities as an effective vehicle for bringing social transformation, economic advancement, and furthering democratic governance. One of the major issues in developing countries like Nepal is how to uplift the economic status of rural people. For this, the government has accepted NGOs as development partners. It would be worthwhile to know about the historical development of Non Governmental Organisations in Nepal which is as below.
\end{abstract}

\section{NON GOVERNMENTAL ORGANISATIONS IN NEPAL BEFORE 1951}

The evolutionary process of NGOs in Nepal from historical prospective has rather been slow compared to the rest of the world. There are very limited references related to the concept of institutionalisation of social service in Nepal. The first pioneering social institution in the history of social service sector of Nepal was 'Gandhi Memorial Charkha Pracharak Guthi.' During the great earthquake of 1934, two social organisations came into existence namely 'Bhukampa Sewa Dal' and 'Maharaja Servant Society'. The basic function of this entity was to provide relief to the earthquake victims. There seems to have been no trace of this organisation after the post quake period.

In ancient period particularly during the Lichhavi period, social works were institutionalised through the Guthies. They were the unique organizations formed to manage the diverse work of special upliftment and welfare. In the interest of efficiency, each Ghosti like was given charge of particular work. These institutions managed the donation and conducted many public welfare works. Very often Lichhavi Kings granted tax free land and provided many other privileges to the Gosties to perform their duties promptly and efficiently (Jha, 1970: 7).

During the medieval Nepal, there existed several organisations engaged in the work of mobilizing social works for the welfare and betterment of needy. The social organization engaged in the field of social works can be classified into three types (a) Panchayat, (b) Gosthis and Guthis and (c) Sevakhalak.

In ancient Nepal, local Panchayats of the medieval period were also engaged in various social welfare works like construction of public inns, resting place (Pati, Pauwa) water conduct etc. During this period, Guthis were the main medium for mobilization of public works. Many Guthis came into existence as a step to provide endowment for the up keep of temple, and domestic observance and rites. Many Guthis supervised spouts inns, resting places, and the beautiful monuments,

Dr. Singh is an Associate Professor at Research Division, T.U., Kirtipur, Kathmandu, Nepal. 


\section{HISTORICAL DEVELOPMENT OF NON ..}

rich heritages, series and temples, etc. Some of them were formed to provide economic support for the continuance of religious rites connected with a temple. The Guthis also entertained people by organizing dramas of which many of them are still continuing. The concept of people's participation was implicit in the functioning of Guthi. These unities among the local people and this guided the socio-culture life of the society.

As in Ancient Nepal, the various Panchayats of the medieval period were involved in diverse social works. In fact, the village Panchayats were the people's court for the locality and heard all minor cases and gave them judgements. Several inscriptions of the period have mentioned Panchas and Panchayats. In addition to their administrative works, the Panchayats were involved in the social religious projects (Regmi, 1966: 739).

Sevakhalak was purely a social institution of the medieval period like the Guthi. The Sevakhalak was also involved in socio-religious activities but the latter was not provided with resources to the same degree as the former. In fact, the Sevakhalak was a group of people of a particular locality who voluntarily undertook the task of repairing temples, Chaityas, and public monuments

It is said that the expenses for the task were met by contribution, and the members of the Sewakhalok themselves contributed liberally for the advancement of the public works (Ibid, 1966). The Sebakhalak literally means a group of people involved in the work of rendering different types of services to the needy. In fact the present clubs and voluntary institutes in some ways resemble the medieval Sebakhalak. One great difference between the two is that the Sebakhalak's services were rendered in a particular areas whereas the present clubs have extended their services in many areas. (Shah, 1986: 72).

In the History of modern Nepal Prithivinarayan Shah, the unifier of Nepal stands as the first social worker and reformer. He wanted his subjects to be happy and prosperous, and thus his policies were always directed towards the betterment of the Nepali people as a whole. During the last days of his life, Prithivinarayan delivered along lecture at Nuwakot, which became a guideline to his successor Kings, courtiers and the people as well. Better known as Dibya Upadesh (Devine Counsel), it contains many references to the social services to be conducted by the king and the people for the overall development of the country and people (Stiller, 1968: 38-46).

Prithivinarayan Shah proudly claimed Nepal to be a "garden of four castes (Jaat) and thirty six classes (varna)." This phrase is an indication of the King's benevolent attitude and his policy of treating all Nepali people equally. He further noted "If the citizen are wealthy, the country is strong; the king's storehouse is his people" (Ibid: $38-46)$. It was a period when social service meant performing some pious deeds while keeping in view the welfare of the people. These Act included the constructions of temples, roads, bridges, Dharmasalas, wells etc. for the people in general. All these activities helped to develop the concept of the social service which during the second half of the $19^{\text {th }}$ century was to express in the form of legal enactments and organised as systematic programmes.

Similarly during the Rana Regime, socio-cultural non-governmental institutions existed even though the government was suspicious that the 
organisations would indulge in anti-Rana activities. Apart from conventional Guthis the prominent organisations were, Shree Chandra Kamadhenu Pracharak Mahaguthi, founded by Tulsi Mehar in 1926 and Paropakar Ausadhalaya founded by Daya Bir Kansakar in 1941. The founded organisation aimed at developing cottage industry through Charkha to produce sufficient quantity of cloth for the people. To run this institutes fund was collected from the people. They later functioned as a private dispensary with a motive to distribute medicine to the poor people free of cost. After the end of Rana regime, Tulsi Mehar founded another organisation, Nepal Gandhi Smarak Nidhi. In 1972 these two organisations were incorporated in to one under a new name, Nepal Charkha Pracharak Gandhi Smarak Mahaguthi. This organisation has contributed immensely and has rendered valuable service to the society by opening schools, orphanage, and by providing help to disabled persons. It has also helped opening various types of cottage industries. In this way Paropakar Ausadhalaya as Paropakar Association dedicated the task of serving the poor and disabled, establishing a free hospital for them .With the advent of new era after 1950, a number of social organisation (NGOs) came into existence, such as Nepal Scout, Nepal Tuberculoses eradication, Marwari Sewa Samiti, Rotary Club, Nepal Children Association, Nepal Red Cross, Leprosy Eradication Association, etc. In short large number of Non- Governmental Organisations came in to being after the advent of democratic era in Nepal. Some of these are affiliated and worked as agencies of International Organisation such as SOS, Children Village, Rotary Club, Nepal Lions Clubs, etc while others were indigenous (Mall and Upadhyaya, 1988: 10).

As society forged ahead and advanced the scope, the role of NGOs has broadened its realm become all social problem-poverty sickness, suffering and social disorganisations have existed throughout human history. Until the nineteenth century, the family and community were able to deal with all but the most overwhelming social catastrophists could not be meted. But as societies became industrialized these institutions become increasingly inadequate to handle many new social problem created by population movement and technological changes. A more formal system of social services was need. The concept of social welfare as scientific programmes to ensure the satisfaction of basic human needs thus developed in industrialized societies (Fredlander and Robert, 1982: 3).

\section{NON GOVERNMENTAL ORGANISATIONS IN NEPAL AFTER THE INCEPTION OF DEMOCRACY IN 1951}

Non-Governmental Organisations and voluntary action have been a part of historical legacy. After the inception of democracy in 1951 large number of organisation came into existence with the avowed purpose of serving the people consequently. According to the registration record in Social Service Coordination Council, the number of such voluntary organisations is increasing 300 (Upadhya, 1987: 16). Besides, there are some other associations and clubs which are not registered in the list of any Coordination Committee. The activities of these unregistered associations and clubs are also limited within the accessible urban centre of the Kingdom.

In addition to the national NGOs multinational voluntary agencies have also emerged in the country. Majority of the multinational voluntary organisation in Nepal so far registered are found to have been active in the field of rural development and health services. But some of them cater to the needs of orphan and disabled residing in the 
country. Volunteers from different countries are found to have been active and hard working and contributing a lot in the upliftment of the people in the backward regions in the country. They have launched various Community Development Programmes.

Within these three decades there has been a mushroom growth of voluntary social welfare organisations. As such, growth of this organisation has led to several like duplication of functions, low level of input, diminishing quality of output. So these seem to be a need of one window policy for the NGOs which is proficiently manned, properly represented by all the line ministries having to deal with NGOs is vested with the sole authority to deal with NGOs in its entirety, ranging from donors entry, issuance of visas, processing documents related to importation of project goods, provision for consultants, tax rebates and exemptions till the signing of the agreement etc.

SOCIAL SERVICE NATIONAL COORDINATION COUNCIL AND SOCIAL WELFARE COUNCIL IN NEPAL

NGOs play an important role in national development of the country. Public welfare activities based on the tradition of gaining religious merit and fame, promoting the welfare of others, and assisting the people. So the non government organisation formally began 66 years ago after the establishment of different organisation through the effort of social workers. With the increase in the number of organisations, the insufficiency of government acts, rules, policies, and plans to integrate and promote such organisation was felt. The non-government organisations also felt the need for the central organisation. At the government level also an organisation was felt necessary to promote social welfare and involve nongovernmental organisations with government efforts. So His Majesty King Birendra Bir Bikram Shah Dev established the Social Service National Co-ordination Council on $13^{\text {th }}$ Feb. 1977 under the chairmanship of Her Majesty Queen Aishwarya Rajya Laxmi Shah on September 1977. The Ministry of Social Welfare was formed in 1981 with the aim of promoting non-government efforts, now there is a Ministry of Women Development and Social Welfare (1995).

Late His Majesty the King Birendra Bir Bikram Shah Dev promulgated the Social Service National Co-ordination Council Act called Samajik Sewa Ain was enacted and SSNCC was established as a government bureau. The Sangh Sanstha Ain 2034 covered all voluntary institution while the Samajik Sewa Ain (Social Service Act) covered social welfare organization authorised by SSNCC.

There were six coordination committee under SSNCC. There were: Health Services Co-ordination Committee, Women's Services Co-ordination Committee, Community Service Co-ordination Committee, Children's Welfare Co-ordination Committee, Youth Activities Co-ordination Committee and Hindu Religion Service Co-ordination Committee.

On the basic of the activities NGOs were categorized under any one of the coordination committees. The role of SSNCC was to work as an umbrella organisation for all the NGOs working in the country. This organisation was supposed to work for the promotion, facilitation, coordination, monitoring and evaluation of the activities of the non-governmental organisation in Nepal.

The Act defined the following as the function for SSNCC:

(1) to avoid duplication and maintain coordination among various social organisation; 
(2) to maintain maximum possible uniformity in national, foreign and international donation/grants, and to formulate national policies and programmes;

(3) to mobilise and direct the efforts of social welfare agencies in a coordinated way towards programmes of national development;

(4) to maintain harmonious relations and good understanding among people and communities of different orientations;

(5) to promote interest and welfare of children, youth, old age people, women and handicap people (Samajik Sewa Ain, 2033).

The Act made the SSNCC as the central coordination agency where both the welfare and development programme could be related to each other. Furthermore, the multidimensional role entrusted to it imply that all matters related to the social roles sector, from policy formulation to NGO capacity building, constituted elements of its overriding concerns.

The council is seeking to encourage the development of programmes at grassroots level that will have positive impact socially, physical, mentally and economically on the social workers. Similarly the council has been active in establishing links with the various international organisations to obtain their cooperation in implementing various programmes. The councils has obtained membership in the International Council on Social Welfare in 2034 B.S. (1978) and the Council was elected as an executive member in 2037 B.S. As a result, proper relationships have been established with 35 international agencies. The cooperation extended to the council by the different international agencies has proved a great assistance in the effort to mobilise social services (Shah, Mishra and Pokharel, 246).

Up to early 1960s, almost 15 NGOs were registered for the social services in Nepal. In 1977, some 37 NGOs came into existence and affiliated with Social Service National Coordination Council (SSNCC), a government bureau for coordinating and facilitating the NGOs. The number of affiliation has increased gently up to 220 NGOs including 52 INGOs up 1990 (Marker and Tamang, 1995).

Thus, Social Service National Coordination Council (SSNCC) has achieved miraculous progress within a short span of time. The social service sector is in fact not only concerned with the accusing of financial resources but also with efforts to bring positive change to social consciousness and social action. The council's mission is to mobilize the efforts of the governmental organisation, social organisation, social workers and the mass media to usher in a better tomorrow.

Although non-governmental organisations have developed and expanded to such an extent, these NGOs have not been able to become self reliant and to burgeon as expected, neither could the resources of the private sector be diverted to the development process as desired. So, after the Nepal Democratic Movement (NDM) of 1990s Nepal has witnessed on overwhelming growth of NGOs. SSNCC was dissolved and it was given the new name, Social Welfare Council (SWC) with the passing of the Social welfare Act in 2048 (1992) while the SSNCC Act of 2034 (1978) primarily attached the importance to the institution (SSNCC), the Society Welfare Act 2049 (1993) has encompassed the entire concerns of the social work sector. It has empowered the HMG to undertake the welfare programs addressed to the disadvantage groups- women, children, aged persons, handicapped etc. SWC 
divided whole NGOs in various groups each and every group is related to its own field of improvement. They were Children Welfare, Women Development, Health Services, Services to the Handicapped and Disabled, Community and Rural Development, Youth Development, Moral Development, Environment Protection, ,Educational Development, and HIV/AIDS and Drug Control.

After the enactment of Social Service Act 1992, SWC established a new manager of NGOs replacing the existing SSNCC. The Social Welfare Council Act entrusted SWC as an autonomous body responsible for promotion, facilitation, coordination, monitoring, and evaluation of the activities of the non-governmental social organisations in Nepal. It is also responsible for the extension of its supports to the government in the matters of developing the NGO sector policies and programmes of the nation and to implement them in a co-ordinated way. Apart from these, the council also delivers training to the NGO workers and provides small grants and back-up supports to the local/national NGOs affiliated with this organisation. It also creates the necessary environment to link the local NGOs with the international NGOs and assists to develop partnership between them for the implementation of their activities.

\section{ROLE AND FUNCTIONS OF SOCIAL WELFARE COUNCIL}

(1) Promote, facilitate, co-ordinate, monitor, supervise and evaluate NGO activities; provide possible assistance for the establishment, promotion, extension and strengthening of NGO activities;

(2) Function as a co-ordinating body between HMG and NGOs;

(3) Advise and suggest to the government in the formulation of plans, policies, and programmes related to social welfare and service sector;

(4) Establish trusts or funds for social welfare activities and encourage others to do the same;

(5) Conduct training, undertake studies and research on social welfare subjects;

(6) Do the physical verification of NGO assets;

(7) Undertake necessary measures for the execution of the aims and objectives of the act;

(8) To avoid duplication and maintain co-ordination among various social organisations;

(9) Enter into agreement or contract with foreign and international agencies; and

(10) Make an effort in procuring national and international assistance and use it judiciously (Social Service Council Act, 1992, Article 9).

To perform all these functions the act provided for three important bodies- SWC Council, SWC Management Committee, and SWC Secretariat. A 19-membered Council is the supreme body, meeting once in a year to discuss and approve the policies, plan, programmes, and budgets. The Minister for Women, Children and Social Welfare Council (SWC), while the other members are either nominated by the government or from among the organisational representatives as per the Council Act which is given in Table 1. 
Table1: Social Welfare Council Body

\begin{tabular}{|l|c|l|l|}
\hline \multicolumn{1}{|c|}{ Post } & No. & \multicolumn{1}{|c|}{ Representing } & \multicolumn{1}{c|}{ Remarks } \\
\hline Chairperson & 1 & $\begin{array}{l}\text { Minister for Women, Children and Social } \\
\text { Welfare }\end{array}$ & Ex-officio \\
\hline Vice Chairman & 1 & Social Worker & Government Nominee \\
\hline Member-Secretary & 1 & Social Worker & Government Nominee \\
\hline Treasurer & 1 & Social Worker & Government Nominee \\
\hline Member & 1 & Member, NPC (Social Sector) & Representative Member \\
\hline Member & 1 & Parliamentarian, Social Committee & Representative Member \\
\hline Member & 3 & NGO Representative & Government Nominee \\
\hline Member & 4 & Social worker (at least 1 female) & Government Nominee \\
\hline Member & 6 & MoWCSW, MoH, MoLD, MoF, MoH, MoE & $\begin{array}{l}\text { HMG/Ministry } \\
\text { Representative }\end{array}$ \\
\hline
\end{tabular}

Source: Social Welfare Council Act, 1992, 'Article 16'.

A 7-membered Management Committee, also chaired by Chairperson of the SWC Council, normally plays an executive role and meets monthly to implement SWC activities. SWC Secretariat implements the SWC plans and programmes. The Member-Secretary works as executive head of the SWC Secretariat. The Secretariat is responsible for co-ordinating Ministry of Women, Children and Social Welfare, other concerned functional line ministries, and the Planning Commission at the one end, and the affiliated NGO/INGOs to the other end. The Secretariat is organised with four departments: Planning and Programme Department, Monitoring and Evaluation Department, General Administration Department, and Financial Administration Department. The organisational chart of SWC is given in Figure 1.

Figure 1: Organisational Structure of SWC

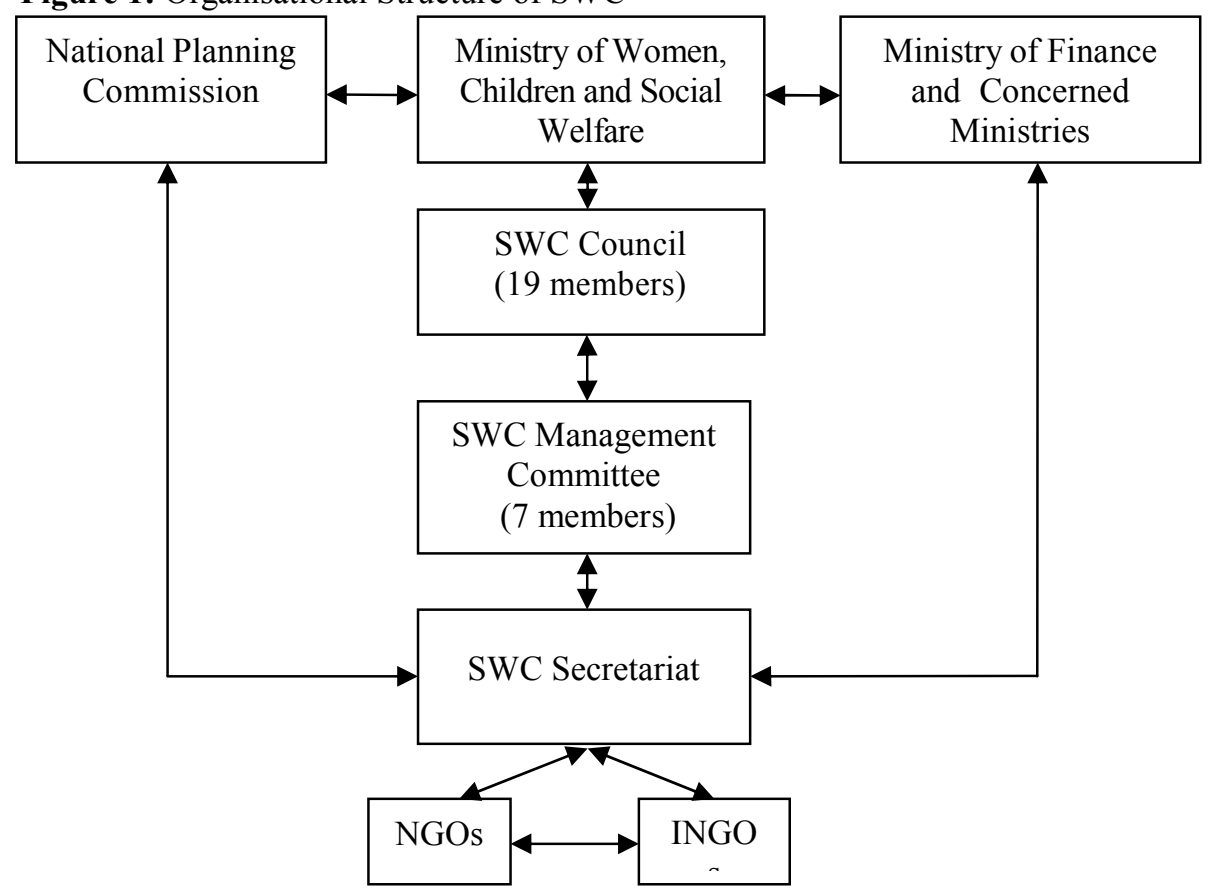

Source: Social Welfare Council Act, 1992. 
Though the SWC is expected to play a dynamic role for co-ordinating and managing the NGOs in Nepal, some problems have made the SWC less effective.

So from all the above discussion it is concluded that NGO is not only the national development partner but also it enhances the quality of life of the Nepalese people.

\section{WORKS CITED}

Fredlander, W.A. and Robert Z.A. (1982). Introduction of Social Welfare. Prcentice Hall of India Private Limited, New Delhi.

Jha, H.N. (1970). The Lichhavis. Chowkhamba, Sanskrit Services Office, Baranasi.

Mall, B..C and Upadhyaya, K.S. (1988). Operational Relationship between Nongovernmental Organization (NGOs) and other Local Institutions. Centre for Economic Development and Administration (CEDA), Tribhuvan University, Kathmandu.

Shah, I.B. (1986). Social Services in Nepal, A Historical Perspective. Social Service National Coordination Council (SSNCC). Kathmandu, Nepal.

Upadhya, K.P. (1987). Study on Participation of Non-government Organization. , Centre for Economic Development and Administration (CEDA), Tribhuvan University, Kirtipur. 